GEOUSP - Espaço e Tempo, São Paulo, № 24, pp. 175 - 176, 2008

\title{
XV ENCONTRO NACI ONAL DE GEÓGRAFOS - O ESPAÇO NÃO PÁRA: POR UMA AGB EM MOVI MENTO
}

\author{
Mário Leal Lahorgue* \\ Lucimar Fátima Siqueira** \\ Elisangela de Fátima Motta Goulart***
}

A 15a edição do Encontro Nacional de Geógrafos (ENG) manteve a tradição de ser o maior evento da Geografia brasileira, com milhares de participantes e aproximadamente três mil trabalhos inscritos. O gigantismo em que se transformou o ENG nos últimos tempos sem dúvida torna o esforço de organização e logística algo que parece limitar sua realização a centros urbanos e Universidades maiores (como é o caso óbvio de São Paulo e a USP locais deste último encontro). Talvez algo que possa ser pensado no futuro seja intercalar os Encontros Nacionais com Encontros Regionais, no intuito de possibilitar que outros centros de Geografia possam também organizar reuniões, além de permitir a participação de pessoas que não podem ou não conseguem se deslocar milhares de quilômetros para o Encontro Nacional.

Um evento deste tamanho tem vantagens e desvantagens. A vantagem é permitir que se tenha um imenso painel do estado atual da Geografia brasileira, além de possibilitar o encontro, discussão e troca de experiências entre pessoas que de outra forma dificilmente se encontrariam. A desvantagem é que se torna impossível acompanhar todos os debates, apresentações de trabalhos e mesasredondas que acontecem simultaneamente, forçando uma escolha que nem sempre o participante gostaria de fazer.

O tema central do evento, "O espaço não pára: por uma AGB em movimento", foi muito feliz em sua dupla perspectiva de a) articular o pensar e o fazer não só da Geografia como de sua relação com as outras Ciências e a Filosofia; b) relembrar e ser um espaço de reflexão sobre os últimos 30 anos de geografia no Brasil, desde o já mítico Encontro de Fortaleza em 1978. Esse segundo aspecto é extremamente importante, pois não se pode esquecer que hoje em dia uma parcela bastante considerável dos presentes no ENG eram muito jovens em 1978 (e mesmo na década de 80), e, portanto, não acompanharam todo o processo inicial de renovação da Geografia. E, não se pode esquecer, só é possível avançar entendendo o que aconteceu retrospectivamente.

O encontro deste ano manteve uma estrutura já conhecida: Grupos de Trabalho (GT), Oficinas, mesas-redondas, Comunicações Coordenadas, Espaços de Diálogos e Práticas (EDP), trabalhos de campo.

Sem dúvida, os Espaços de Diálogo e Prática já se consolidaram como um dos principais eventos dentro do Evento. A possibilidade (democrática) de se trocar idéias durante vários dias com pessoas dos mais diversos graus de formação (Professores, doutorandos, mestrandos ou bolsistas de Iniciação Científica) sobre temas semelhantes ao que se está pesquisando/estudando é uma das coisas mais estimulantes do ENG. Muitos contatos e mesmo amizades são feitos a partir dos EDPs, conectando pessoas que talvez nunca se conheceriam se não fosse por essa via.

* Professor na Universidade do Extremo Sul Catarinense - UNESC. E-mail: mll@unesc.net 
Algo que deveria acontecer, e que esperamos que se concretize com a nova diretoria eleita, é a retomada da revista Terra Livre. Todos reconhecem a importância de um periódico verdadeiramente nacional (sem menosprezar todos os periódicos que com todas as dificuldades são editados por AGBs locais ou Cursos Universitários de Geografia). E não se pode esquecer que hoje em dia é mais fácil (ou menos difícil) editar um periódico pela possibilidade de ele existir em versão eletrônica, tornando-o inclusive mais acessível para geógrafos dos mais diversos pontos do país e do mundo, coisa que uma versão impressa não consegue.

Por fim, queremos dizer que outra coisa deve ser pensada para o próximo encontro em Porto Alegre: os Anais não podem ser feitos unicamente para rodar em computadores com Windows. É inconcebível que uma entidade plural com a AGB reforce o virtual monopólio da Microsoft. Nem todos os Geógrafos usam Windows. E os usuários de Linux? De Macintosh? Não é difícil montar um CD-ROM multiplataforma, basta um pouco de vontade.

Trabalho enviado em setembro de 2008

Trabalho aceito em setembro de 2008 
